\title{
THE GREAT PHILOSOPHER IN ISLAMIC ECONOMY
}

\author{
Lola Fitria Sari
}

\begin{abstract}
Filsafat Ekonomi Islam ini didasarkan pada aspek pemahaman dan keyakinan Islam sebagai agama yang universal dan komperhensif. Universal berarti bahwa Islam diperuntukkan bagi seluruh ummat manusia di muka bumi dan dapat diterapkan dalam setiap waktu dan tempat sampai akhir zaman. Komprehensif artinya bahwa Islam mempunyai ajaran yang lengkap dan sempurna (Kaffah). Kesempurnaan ajaran Islam, dikarenakan Islam mengatur seluruh aspek kehidupan manusia, tidak saja aspek ibadah ritual semata, tetapi juga aspek mu'amalah yang meliputi sosial, politik, budaya, hukum, ekonomi, dan sebagainya.
\end{abstract}

Keyword: Filsafat, Ekonomi islam

Al-Qur'an secara tegas mendeklarasikan kesempurnaan Islam tersebut. Ini dapat dilihat dalam beberapa ayat, seperti pada surat Al-Maidah ayat 3 "Pada hari ini Kusempurnakan bagi kamu agamamu dan Kusempurnakan bagi kamu nikmatKu dan $\mathrm{Aku}$ ridho Islam itu sebagai agama kamu”. Dalam ayat lainnya Allah berfirman, 'Kami menurunkan Al-Qur'an untuk menjelaskan segala sesuatu" (QS.16:89). Kesempurnaan Islam ini tidak saja disebutkan dalam Al Quran, namun juga dapat dirasakan baik itu oleh para ulama dan intelektual muslim sampai kepada non muslim.

Seorang orientalis paling terkemuka bernama H.A.R Gibb mengatakan, "Islam is much more than a system of theologi its a complete civilization" (Islam 
bukan sekedar sistem theologi, tetapi merupakan suatu peradaban yang lengkap). Sehingga menjadi tidak relevan jika Islam dipandang sebagai agama ritual an sich, apalagi menganggapnya sebagai sebuah penghambat kemajuan pembangunan (an obstacle to economic growth). Pandangan yang demikian, disebabkan mereka belum memahami Islam secara utuh.

Islam lebih mengutamakan amal dari pada ide, demikian ungkap Mohammad Iqbal dalam The Reconstruction of Religious Thought in Islam, karena itu Islam dapat terwujud sebagai suatu peradaban.Islam hadir bukan hanya sebagai gagasan agama, namun sebagai benih dan model peradaban yang Kosmopolitan. Al-Quran bukan sekadar sebuah doktrin, melainkan seruan untuk mengungkapkan kasih sayang dalam amal perbuatan: menumpuk harta kekayaan tidaklah baik dan yang baik adalah berbagi kekayaan secara merata dan menciptakan masyarakat yang adil di mana orang miskin dan lemah diperlakukan secara hormat. (Armstrong, 2012:18). Sifat ajaran Islam yang seperti ini mengembangkan jenis peradaban baru yang lebih aplikatif tidak melulu teoritis.

Kunci filsafat ekonomi Islam terletak pada manusia dengan Tuhan, alam dan manusia lainnya. Dimensi filsafat ekonomi Islam inilah yang membedakan ekonomi Islam dengan sistem ekonomi kapitalisme dan sosialisme. Filsafat ekonomi yang Islami, memiliki paradigma yang relevan dengan nilai-nilai logis, etis dan estetis yang Islami yang kemudian difungsionalkan ke tengah tingkah laku ekonomi manusia. Dari filsafat ekonomi ini diturunkan juga nilai-nilai instrumental sebagai perangkat peraturan permainan (rule of game) suatu kegiatan.

Permasalahan besar hari ini, dalam mengkaji ilmu pengetahuan seperti halnya ilmu ekonomi berkembang saat ini yang nota bene di klaim atas nama 
barat, literatur sejarah teori ekonomi biasanya langsung loncat pada masa abad pertengahan di Eropa. Pemikiran ekonomi yang diproduksi oleh para pemikir Islam ditiadakan, bahkan mungkin dianggap tidak ada. Padahal semua pihak mencatat bahwa ada peradaban Islam pada abad pertengahan yang kemudian memunculkan peradaban modern, abad pencerahan. Jadi, seharusnya, pada abad pertengahan itu kemajuan peradaban dan pengkajian ilmu juga berkembang di wilayah peradaban Islam.

Dalam Encyclokipaedia Britania, Jerome Ravetz menulis, ”Eropa masih berada dalam kegelapan, sehingga tahun 1000 Masehi di mana ia dapat dikatakan kosong dari segala ilmu dan pemikiran, kemudian pada abad ke 12 Masehi, Eropa mulai bangkit. Kebangkitan ini disebabkan oleh adanya persinggungan Eropa dengan dunia Islam yang sangat tinggi di Spanyol dan Palestina, serta juga disebabkan oleh perkembangan kota-kota tempat berkumpul orang-orang kaya yang terpelajar".

Dalam konteks inilah perkembangan ilmu ekonomi tidak sepenuhnya milik barat. Dengan demikian keberadaan Filsafat Islam, bagaimanapun, harus diakui sebagai jembatan emas bagi perkembangan pengkajian filsafat di Eropa. Tema pembahasan ekonomi setelah dikemukakan oleh para filsuf Yunani Kuno, seperti Plato dan Aristoteles, juga dibicarakan oleh Filsuf Muslim seperti AlFarabi, Ibn Sina, Ibn Rusyd, Al-Ghazali, dan sebagainya. Kemudian karya mereka menjadi sumber kedua (setelah filsafat Yunani) dalam perkembangan keilmuan ekonomi di Eropa.

Abdul Azis Islahi pada tulisan The Myth of Bryson and Economic Thought in Islam mengekukakan bahwa Filsuf Muslim tidak menerjemahkan The 
Greek oikonomia dengan bahasa Arab 'ilm tadbir al-manzil (the science of household management) namun juga menambahkan ruang lingkup bahasan ekonomi. Jika ekonomi Yunani terbatas pada pembahasan gagasan, 'wants and their satisfactions', 'economy of self sufficient households', 'division of labour', 'barter', and 'money' Filsuf Muslim memperluasnya ke wilayah market function and pricing mechanism, production and distribution problems, government economic role and public finance, poverty eradications, and economic development, etc. Kesimpulan Islahi ini diperkuat dengan tulisan Spengler (1964, p. 304) yang menegaskan bahwa "Muslim scholars extended this branch of knowledge 'far beyond the household, embracing market, price, monetary, supply, demand phenomena, and hinting at some of the macro-economic relations stressed by Lord Keynes'."

Kesimpulan Islahi ini menunjukkan adanya perluasan bahasan ekonomi dari pemikiran Yunani ke wilayah yang lebih luas. Ekonomi tidak sekadar pengurusan kebutuhan rumah tangga masyarakat, melainkan lebih dari itu. Situasi perluasan ini dapat dipahami karena peradaban Islam telah berkembang sedemikian rupa sehingga berhadapan dengan sejumlah permasalahan baru yang sebelumnya tidak ditemukan pada zaman Yunani.

\section{Sejarah Pemikiran Ekonomi Islam}

Fase pertama, pemikiran-pemikiran ekonomi Islam baru pada tahap meletakkan dasar-dasar ekonomi Islam, dimulai sejak awal Islam hingga pertengahan abad ke5 H/ 7-11 Masehi. Pada tahap ini pemikiran-pemikiran ekonomi Islam pada umumnya bukanlah dibahas oleh para ahli ekonomi, melainkan dirintis fuqaha, sufi, teolog, dan filsuf Muslim. Pemikiran ekonomi Islam pada tahap ini banyak 
ditemukan dalam kitab-kitab turats (peninggalan ulama). Dari turats itulah para intelektual Muslim maupun non-Muslim melakukan kajian, penelitian, analisis, dan kodifikasi pemikiran-pemikiran ekonomi Islam yang pernah ada atau dikaji pada masa itu. Pemikiran-pemikiran ekonomi yang terdapat dalam kitab tafsir, fiqih, tasawuf dan lainnya, adalah produk ijtihad sekaligus interpretasi mereka terhadap sumber Islam saat dihadapkan pada berbagai kegiatan-kegiatan ekonomi dan persoalan-persoalan ekonomi yang dihadapi masa itu.

Fase kedua adalah berlangsung dari abad 11- 15. Pada masa ini para fuqaha, sufi, filsuf, dan teolog, mulai menyusun bagaimana seharusnya umat Islam melaksanakan berbagai aktivitas ekonomi. Tidak hanya merujuk pada Al-Quran dan tradisi kenabian, tapi juga mulai mengemukakan pendapat-pendapatny a sendiri.

Fase ketiga adalah stagnasi, ditandai dengan kemunduran Dunia Islam dalam khazanah intelektual, sejak 1446 hingga munculnya pemikir Muhammad Iqbal pada 1932.

Fase keempat adalah modern, ditandai dengan kebangkitan Dunia Islam dari stagnasi pemikiran selama lima abad sejak pertenghaan abad ke-15 hingga pertengahan abad ke-20. Pada masa modern ini muncul pakar-pakar ekonomi Islam profesional.

Jika pembahasan ekonomi sebelumnya dilakukan para fuqaha, teolog, filsuf, dan sufi, maka pada masa modern ini dikembangkan kalangan sarjana ekonomi atau cendekiawan Muslim,yang tidak sedikit mendapat pendidikan Barat. Sebuah jejak perjalanan pemikiran ekonomi Islam. Sebuah kekayaan yang pantas kita banggakan dan hadirkan dengan kontekstualisasi dan pengembangan nalar 
sehingga relevan dengan zaman sekarang. Memang harus diakui bahwa pascatumbangnya Komunisme, Sosialisme, Liberalisme dan sistem ekonomi Kapitalisme yang menjadikan krisis global di negara-negara Barat dan yang berada di bawah naungannya, termasuk Indonesia, para ekonom Barat mencari "formula" yang kemampuan, kekuatan, dan kehebatannya melampaui sistem dan pemikiran yang sebelumnya. Mereka melihat pada Islam, khususnya pada khazanah pemikiran ekonomi yang dikemukakan para ulama dan cendekiawan Muslim. Tidak sedikit karya khazanah ekonomi Islam itu diadaptasi dan dikembangkan di negara-negara Barat sekarang ini. Bedanya dengan di negerinegeri Islam adalah, ekonom Barat mengambil sistem dan konsepnya tanpa mengambil sisi spiritualitasnya. Mungkin, bisa diibaratkan bentuk tanpa isi. Namun, meski begitu geliatnya dalam mewujudkan sistem yang berdasarkan syari ah sangat tampak dari beberapa perusahaan yang ada di Eropa, khususnya di Inggris sudah muncul perguruan tinggi yang mengajarkan Islamic finance dan di Jepang untuk kawasan Asia. Mengapa mesti ekonomi Islam yang menjadi solusi dalam membangun sistem perekonomian yang utuh dan paripurna?

Ciri-ciri Ekonomi Islam :

Pertama : adalah ekonomi Islam berlandaskan pada tauhid (Ilahiyah).

Kedua : adalah mengutamakan keadilan.

Ketiga : adalah kemanusiaan, terutama dalam berbagi kepada yang kurang mampu secara finansial dan belum berdaya. 
Keempat adalah menjunjung kebebasan, melepaskan manusia dari beban dan rantai yang membelenggunya karena Islam menjunjung kebebasan, berarti kreasi, inovasi dan improvisasi untuk hal-hal yang baik dan bermanfaat adalah keharusan.

Kelima adalah akhlak. Islam menghubungkan masalah mu`amalah dengan etika, seperti kejujuran, amanah, adil, ihsan, kebajikan, silaturrahim, dan kasih sayang. Semua itu harus tercermin dalam semua kegiatan ekonomi, mulai dari produksi, sirkulasi dan perdagangan hingga konsumsi.

\section{Pemikiran Ekonomi Abu Yusuf (112-182H./731-789H.)}

Abu Yusuf lahir pada tahun $113 \mathrm{H}$, pernah tinggal di Kufah dan di Bagdad, meninggal pada tahun $182 \mathrm{H}$. Menurut penuturannya beliau menjadi murid Abu Hanifah selama 17 tahun dan sejumlah ulama terkemuka pada masa itu. Beliau juga tercatat sebagai murid dari Ibn Abi Laila, imam Malik dan sejumlah ulama lainnya. Panggilan populernya adalah Qadli Qudhat (hakim agung) yaitu jabatan yang disandangnya pada masa kekuasaan khalifah Harun al-Rasyid. Perhatiannya banyak terfoks pada keuangan umum dan peran negara, pekerjaan umum, dan perkembangan pertanian. Ia pun dikenal sebagai penulis pertama buku perpajakan yang dinamainya Kitab al-Kharaj.

Abu Yusuf menjadi salah satu dari dua referensi utama fiqh dalam mazhab Hanafi. Pengetahuannya tentang hadis juga tidak dapat diremehkan. Ini terlihat dalam kitab al-Asar karya putranya Yusuf. Kitab ini sarat dengan wacana fiqh Abu Hanifah dan Abu Yusuf.

Keunggulan karya Abu Yusuf dalam bidang fiqh karena ditulis dengan metode: 
Pertama, menggabungkan metode fuqaha' (aliran ra'y) di Kufah dengan metode fuqaha' (aliran al-hadis) di Madinah.

Kedua, rumusan hukumnya sejalan dengan fenomena aktual di tengah masyarakat sehingga sangat aplikatif dan realistis. Pengalamannya dalam menyelesaikan kasus-kasus rill, membuatnya banyak menghindar dari rumusan fiqh yang asumtif.

Ketiga, bebas dalam berpendapat. Kemampuan Abu Yusuf menggabungkan metode fuqaha' aliran ra'yi dan aliran hadis membentuknya menjadi faqih independen, tidak berpihak kepada pendapat tertentu secara subyektif. Beliau melakukan ijtihad secara mandiri dan tidak terpengaruh oleh pendapat guru-gurunya.

Keempat, komitmen pada sumber-sumber tekstual dan rasional. Metode ini menjadi tradsisi para ulama ahl al-ra'y yang menggunakan nalar qiyas dan nalar istihsan serta mempertimbangkan al-'urf.

Dalam bidang ekonomi, terutama dalam kitab al-kharaj, Abu Yusuf pun menggunakan motode-metode tersebut. Kitab al-Kharaj, merupakan jawaban atas pertanyaan-pertanyaan yang diajukan oleh khalifah Harun al-Rasyid dan pertanyaan-pertanyaan yang dibuat sendiri oleh Abu Yusuf. Jawaban atas semua pertanyaan tersebut diperkuat oleh dalil-dalil aqli dan naqli Abu Yusuf menggunakan pendekatan rasional dalam menyimpulkan 'ilal al-hadis. Abu Yusuf tidak mengabaikan praktek faktual para sahabat (a'mal al-sahabah) sejauh itu relevan dengan situasi yang ada mengingat kemaslahatan umum selalu menjadi pertimbangan utama.

Istilah al-kharaj dalam prespektif Abu Yusuf mengandung dua makna: 
Pertama, makna yang berdimensi umum yaitu al-amwal al-'ammah (keuangan umum), atau sumber pendapatan Negara seperti ganimah, fai', al-kharaj, aljizyah, dan harta-harta yang berkedudukan sebagai pengganti seperti al-kharaj seperti 'usyur al-tijarah, dan sadaqah.

Kedua, makna al-kharaj yang berdimensi khusus yaitu sewa tanah atau kompensasi atas pemanfaatan tanah. Dengan demikan, istilah al-amwal sinonim dengan istilah al-kharaj yaitu keuangan umum atau sumber pendapatan negara. Pemaknaan al-kharaj secara sempit dan khusus, kata Dhiya' al-Din al-Ris muncul dan dipelopori oleh fuqaha' pasca Abu Yusuf, tetapi pemunculan tersebut tidak mempengaruhi makna dasar al-kharaj.

Abu Yusuf adalah orang pertama kali memperkenalkan konsep perpajakan di dalam karyanya al-kharaj. Kitab ini, ditulis atas permintaan Khalifah Harun al-Rasyid, ketika dia ingin mengatur sistem Bait al-mal, sumber pendapatan Negara dan cara pendistribusiannya, dan untuk menghindari manifulasi, kedzaliman, serta untuk mewujudkan kepentingan penguasa.

Al-Kharaj dan visi strategisnya disamping memuat konsep terhadap kebijakan sumber pendapatan Negara, juga mempertegas bahwa ilmu ekonomi adalah bagian tak terpisahkan dari seni dan menejemen pemerintahan dalam rangka pelaksanaan amanat yang dibebankan rakyat kepada pemerintah untuk mensejahterakan mereka. Dengan kata lain, tema sentral pemikiran ekonominya menekankan pada tanggungjawab penguasa untuk mensejahterakan rakyatnya. Ia adalah peletak dasar prinsip-prinsip perpajakan yang dikemudian hari "diambil" oleh para ahli ekonomi sebagai canons of 
taxation. Sedangkan pemikiran kontroversialnya ada pada sikapnya yang menentang pengendalian dan penetapan harga (tas'ir).

Dapat dipastikan, bahwa konsep "ekonomi makro" tidak ditemukan dalam al-kharaj karya Abu Yusuf, dan juga belum dikenal di dunia Barat sampai beberapa abad pasca Abu Yusuf. Kegiatan prekonomian, kata Abu Yusuf merupakan fenomena yang selalu berubah-ubah (zawahir tsanawiyah) dan bersumber dari aktivitas kolektif masyarakat muslim.

Faktor-faktor yang mempercepat kegiatan perekonomian tidak sama dari segi tingkat kepentingan dan kekuatannya:

Pertama, mewujudkan undang-undang tertinggi yang dengannya dapat memerintah dengan pertolongan Tuhan.

Kedua, usaha untuk memenuhi kebutuhan material dan keinginan-keinginan lainnya.

Ketiga, inisiatif atau keinginan penguasa.

Oleh karena itu, kata Abu Yusuf, fenomena prekonomian tidak selalu berhubungan secara langsung dengan sebab akibat (undang-undang tentang prekonomian). Hubungan biasanya bersifat tidak langsung karena melalui kehendak tertinggi, atau kehendak wakil Tuhan di permukaan bumi dalam bentuk masyarakat muslim, penguasa atau lainnya. Para khalifah Tuhan memiliki wewenang untuk mengambil keputusan berkaitan dengan sejumlah fenomenafenomena preekonomian seperti perbaikan tanah dan lain-lain.

Sumber ekonomi, menurut Abu Yusuf berada pada dua tingkatan:

Pertama meliputi unsur-unsur alam (antara lain air dan tanah). Unsur-unsur ini paling kuat dan melakukan produksi secara mandiri. 
Kedua tenaga kerja. Tingkatan yang kedua ini berperan kurang maksimal dan tidak rutin seperti perbaikan dan pemanfaatan tanah, membuat sistem irigasi dan lain-lain.

Sebetulnya produksi dalam pengertian membuat barang baku (setengah jadi) menjadi produk final melalui kerja, tidak banyak menarik perhatian Abu Yusuf termasuk pada proses permulaan seperti ihya' al-mawaat.

Al-musytarakat al-diniyah (komunitas yang menganut agama samawi dan agama ardhi, dan musytarakat al-mudun atau komunitas masyarakat perkotaan dan pedesaan atau komunitas masyarakat dagang, menurut Abu Yusuf menjadi elemen dalam prekonomian. Komunitas jenis pertama terbentuk dari unsur agama, dan komunitas jenis kedua membentuk pusat kekuasaan pemimpin. Kedua jenis komunitas tersebut mempersatukan, atau minimalnya mempererat hubungan antara semua unsur atau elemen prekonomian tersebut.

Abu Yusuf tidak banyak menyentuh persoalan fakir miskin (fuqora') dan tidak memunculkan konsep kelas sosial. Diskripsi masyarakat yang dibuat Abu Yusuf, mencerminkan bahwa hubungan produksi dari satu sisi merupakan hubungan antara umat Islam dengan kaum zimmi dalam Dar al-Islam atau hubungan umat Islam dengan komunitas non muslim dalam Dar al-harb. Dalam hubungan model pertama pendapatan bersumber dari al-kharaj dan al-jizyah. Sedangkan hubungan model kedua, pendapatan bersumber dari al-ganimah ytang sebagiannya didistribusikan untuk Bait al-mal. Selain itu, pemerintah juga menarik bea cukai dari pedagang kafir harbi atas barang dagangan mereka yang masuk ke negara Islam. Adapun umat Islam diwajibkan untuk mengeluarkan zakat sebagai bentuk solidaritas sosial mereka sesama muslim yang membutuhkan. 
Konsep perdagangan luar negeri, diperkenalkan oleh Abu Yusuf secara inplisit dengan istilah tabadul. Walaupun sistem pasar nyaris dilupakannya. Abu Yusuf juga membuat model distribusi dan alokasi penerimaan ganimah bagi pasukan perang dan seluruh umat Islam.

Kekuasaan menurut Abu Yusuf terdiri dari tiga unsur yaitu: Pertama umat Islam, Kedua pemimpin (imam), Ketiga lembaga-lembaga negara atau pemerintahan antara lain al-jaisy, al-dawawin. Mereka dibebani dengan misi ekonomi yang paling fundamental seperti menetapkan jizyah, membagi ganimah, menetapkan gaji dan tunjangan, memberikan tanah pinjaman, membuat sistem irigasi dan memperbaiki tanah.

Adapun konsep kepemilikan sangat luas dan fleksibel meliputi penanaman modal (istiglal) yang memberikan hak kepada pemiliknya untuk mengambil sebagian atau semua keuntungan, kepemilikan secara aktual, kepemilikan individu dan kepemilikan khusus seperti barang bergerak, kepemilikan umum dan kepemilikan bersama yang diatur oleh pemerintah, kepemilikan terhadap budak. Jenis-jenis kepemilikan ini memiliki karakteristik yang tidak permanen.

Terdapat catatan penting dan umum, khususnya susunan kategori, yaitu agama, ekonomi dan militer. Hal ini terlihat pada konsep hubungan produksi yang fundamental, hubungan pajak tanah dan pajak diri:

Unsur-unsur keagamaan dapat dilihat dari hubungan komunitas muslim dan komunitas zimmi. Unsur-unsur ekonomi terlihat bahwa pendapatan berpindah dari yang kedua (kaum zimmi) ke yang pertama (kaum muslim). Unsur-unsur militer terlihat bahwa hubungan-hubungan tersebut hasil dari perjanjian atau kesepakatan sebagai konsekuensi kemenangan dalam berperang. 


\section{Pemikiran Ekonomi Abu Ubaid (157-224H/774-738M)}

Abu Ubaid dilahirkan di Bahrah, di propinsi Khurasan (barat laut Afghanistan) pada tahun 154 Hijriah. Nama aslinya al-Qosim ibn Salam ibn Miskin ibn Zaid al-Azdhi. Ia belajar pertama kali di kota asalnya, lalu pada usia 20-an pergi ke Kufah, Basrah, dan Baghdad untuk belajar tata bahasa Arab, qirâ'ah, tafsir, hadis, dan fikih. Setelah kembali ke Khurasan, ia mengajar dua keluarga yang berpengaruh. Pada tahun 192 H, Thâbit ibn Nasr ibn Mâlik (gubernur yang ditunjuk Harun al Rasyid untuk propinsi Thughur) menunjuknya sebagai qâdi' di Tarsus sampai 210 H. Kemudian ia tinggal di Baghdad selama 10 tahun, pada tahun $219 \mathrm{H}$, setelah berhaji ia tinggal di Mekkah sampai wafatnya (224 H).

Abu Ubaid mengarang sebuah kompendium mengenai keuangan publik yang dapat dibandingkan dengan kitab al kharaj-nya Abu Yusuf. Kitab al Amwal-nya sangat kaya secara historis dan juga berisi materi-materi hukum Islam yang luas. Karyanya banyak dikutip oleh penulis-penulis Islam, dan telah diterjemahkan ke dalam berbagai bahasa.

Kitab Al-Amwal dari Abu Ubayd merupakan suatu karya yang komprehensif tentang keuangan negara dalam Islam. Buku ini dimulai dengan sebuah bab singkat tentang,"hak penguasa atas subjek (individu dalam masyarakat) dan hak subjek atas penguasa”, yang kemudian dilanjutkan dengan bab mengenai jenis-jenis harta yang dikelola penguasa untuk kepentingan subjek dan dasar-dasar pemikirannya yang dibahas dalam kitab Allah serta Sunnah. Bab- 
bab lainnya yang lebih tebal dari pembahasan bukunya Abu Yusuf membahas mengenai pengumpulan dan pembayaran (disbursement) dari tiga jenis penerimaan yang diidentifikasi dalam bab ke dua, yaitu: zakat (termasuk ushr), khums yaitu seperlima dari hasil rampasan perang dan harta karun atau harta peninggalan tanpa pemilik dan fa'i yang termasuk kharaj, jizyah dan penerimaan lainnya yang tidak termasuk kedalam kategori pertama dan kedua seperti, penemuan barang-barang yang hilang (rikaz) kekayaan yang ditinggalkan tanpa ahli waris, dan lain-lain.

Buku ini dengan kaya melaporkan sejarah ekonomi Islam selama dua abad pertama hijriyah, yang juga merupakan sebuah ringkasan tradisi Islam asli dari Nabi, para sahabat dan para pengikutnya mengenai permasalahan ekonomi. Abu Ubaid tidak hanya sekedar melaporkan pendapat-pendapat orang lain ini, tetapi juga selalu mengakhirinya dengan menjalinkan masalah tersebut secara sistematis, mengungkapkan suatu preferensi atas sebuah pendapat dari beberapa pandangan yang dilaporkan atau memberikan pendapatnya sendiri dengan dukungan beberapa basis syari'ah tertentu atau dengan alasan-alasan rasional. Misalnya, setelah melaporkan berbagai pendapat tentang besarnya zakat yang seharusnya diterima oleh seorang penerima zakat yang berhak, dia dengan keras menyatakan ketidaksetujuannya terhadap mereka yang meletakkan suatu batas tertinggi (ceiling) pada pemberian zakat tersebut. Hal yang terpenting baginya adalah keterpenuhan kebutuhan rakyat dan terselamatkannya masyarakat dari penghancuran yang dilakukan oleh orang-orang yang berkeinginan 'tidak terbatas', bahkan jika hal tersebut harus dilakukan dengan pengeluaran uang yang amat besar pada sebuah kasus tertentu. 
Saat membahas tentang tarif atau persentase untuk pajak tanah dan polltax, ia menyinggung tentang pentingnya keseimbangan antara kekuatan finansial dari subyek non-Muslim, dalam finansial modern disebut sebagai "capacity to pay" dan juga memperhatikan kepentingan para penerima Muslim. Ia membela pendapat bahwa tarif pajak kontraktual tidak dapat dinaikkan tapi dapat diturunkan jika terjadi ketidakmampuan membayar serius. Abu Ubaid berupaya untuk menghentikan terjadinya diskriminasi atau penindasan dalam perpajakan serta terjadinya penghindaran terhadap pajak

\section{Zaid bin AH (80-120 H. /699-738 M)}

Zaid adalah penggagas awal penjualan suatu komoditi secara kredit dengan harga yang lebih tinggi dari harga tunai.

\section{Abu Hanifah (80-120H//699-767M)}

Abu Hanifah lebih di kenal sebagai imam madzhab hukum yang sangat rasional dan dikenal sebagai penjahit pakaian atau taylor dan pedagang dari Kufah, Iraq, ia menggagas keabsahan dan kesahihan hukum kontrak jual beli dengan apa yang dikenal dewasa ini dengan bay' al-salam dan murabahah.

\section{Al-Awza'i (88-157H./707-774M.)}

Nama lengkapnya abdurahman al-awza'I yang berasal dari beirut, Libanon dan hidup sezaman dengan abu hanifah. Ia adalah penggagas orisinal dalam ilmu ekonomi syari'ah. Gagasan-gagasannya, antara lain, kebolehan dan kesahihan sistem murabahah sebagai bagian dari bentuk murabahah dan membolehkan peminjaman modal, baik dalam bentuk tunai atau sejenisnya.

Imam Malik Bin Anas (93 -179H./712-796.) 
Imam malik lebih dikenal sebagai penulis pertama hadits al-muwatha', dan imam madzhab hukum. Namun, ia pun memiliki pemikiran orisinal di bidang ekonomi, seperti: Ia menganggap raja atau penguasa bertanggungjawab atas kesejahteraan rakyatnya. Para penguasa harus peduli terhadap pemenuhan kebutuhan dasar rakyat. Teori istilah dalam ilmu hukum Islam yang diperkenalkannya mengandung analisis nilai kegunaan teori utility dalam filsafat barat yang kemudian hari diper-kenalkan oleh Jeremy Benthan dan John Stuart Mill. Disamping itu, ia pun tokoh hukum Islam yang mengakui hak negara Islam untuk menarik pajak demi terpenuhi-nya kebutuhan bersama.

\section{Abu Hamid AI-Ghazali (1059-1111)}

Tokoh lebih dikenal sebagai sufi dan filosof serta pengkritik filsafat terkemuka ini melihat bahwa uang bukanlah komoditi, melainkan alat tukar (medium of exchange).

\section{Tusi (1201-1274)}

Tusi adalah penulis buku dalam bahasa Persia, Akhlak-i-nasiri yagn menjelaskan bahwa: apabila seseorang hamba tetap menghasilkan makanan, pakaian, rumah, dan alat-alatnya sendiri, tentu dia tidak akan dapat bertahan hidup karena tidak akan mempunyai makanan yang cukup untuk jangka lama. Akan tetapi, karena orang bekerja sama dengan lainnya dan setiap orang melakukan pekerjaan sesuai dengan profesinya sehingga mereka menghasilkan konsumsi yang lebih dari cukup untuk dirinya sendiri. Keadilan hukum pun mengendalikan pertukaran produk barang-barang yang menjamin ketersediaannya untuk semua orang. Dengan demikian, Tuhan dengan segala kebijaksanaan-Nya, membedakan aktivitas dan cita rasa orang sedemikian rupa, sehingga mereka mung-kin 
melakukan pekerjaan yang berbeda-beda untuk saling membantu. Perbedaanperbedaan inilah yang melahirkan struktur internasional dan sistem ekonomi umat manusia. Maka terjadilah kerjasama timbal balik. Timbulah berbagai bentuk kontrak sosial.

\section{Ibnu Taimiyyah (1262-1328)}

Ibnu Tamiyyah dalam kitabnya, al-siyasa't al-syari'ah fi' ishla'h al-ra-iy wa alra'iyyah menegaskan tugas, fungsi dan peran pemerintah sebagai pelaksana amanat untuk kesejahteraaan rakyat yang ia sebut ada' al-Ama 'nat 't ila' Ahliha'. Pengelolaan negara serta sumber-sumber pendapatannya menjadi bagian dari seni olah negara (al-Siya'sa'i al-Syar'iyyah) pengertian siyasah al-Dusturiyyah maupun al-Siyasa'i al-Ma'liyyah (politik hukum publik dan privat). Sedangkan dalam karya lainnya, al-Hisbah fi' al-Isla'm lebih menekakankan intervensi pemerintah dalam mekanisme pasar' pengawasan pasar, hingga akuntansi yang erat kaitannya dengan sistem dan prinsip zakat, pajak, dan jizyah. Dengan demikian, seperti halnya Abu 'Ubayd, nampakanya Ibn Taimiyyah mempunyai kerangka pikir yang sejalan dalam pendapat yang menyatakan bahwa ekonomi syari'ah, baik sistem maupun hukumnya merupakan bagian yang tak terspisahkan dari sistem pemerintahan dan katatanegaraan.

\section{Ibn Khaldun (1332-1406)}

Cendikiawan yang berasal dari Tunisia ini lebih dikenal sebagai Bapak ilmu sosial. Namun demikian, ia tidak mengabaikan perhatiannya dalam bidang ilmu ekonomi. Walaupun kitabnya, al-muqadimah, tidak membahas bidang ini dalam bab tertentu, namun ia membahasnya secara berserakan di sana sini. Ia mendefinisikan ilmu sosial jauh lebih luas daripada definisi Tusi. Ia dapat melihat dengan jelas 
hubungan antara ilmu ekonomi dengan kesejahteraan manusia. Referensi filosofisnya yang merujuk kepada "ketentuan akal dan etika" telah mengantarnya kepada kesimpulan bahwa ilmu ekonomi adalah pengetahuan normatif dan sekaligus positif. Terminologi jumhur yang berarti massa yang digunakannya menunjukkan bahwa mempelajari ekonomi adalah untuk meningkatkan kesejahteraan massa, bukan individu. Individu adalah bagian dari jumhur. Hukum ekonomi dan sosial berlaku pada massa, bukan pada individu yang terkucil. Ia melihat hubungan timbal balik antara faktor-faktor: ekonomi, politik, sosial, etika, dan pendidikan. Ia pun mengetengahkan gagagasan ilmu ekonomi yang sangat mendasar, yakni; pentingnya pembagian kerja, pembakuan terhadap sumbangan kerja terhadap teori nilai, teori mengenai pertumbuhan penduduk, pem-bentukkan modal, lintas perdagangan, sistem harga dsb. Pemikirannya kiranya dapat disejajarkan dengan penulis klasik sekaliber Adam Smith, Ricardo, Malthus dan penulis neo klasik sekaliber Keynes.

\section{Al-Mawardi (w.450H.)}

Penulis al-Ahkam al-Sulthaniyyah, adalah pakar dari kubu Syafi'iyyah yang menyatakan bahwa insitusi negara dan pemerintah bertujuan untuk memelihara urusan dunia dan agama atau urusan spiritual dan temporal (li hara'sat al-di'n wa al-umu al-dunyawiyyah). Jika kita amati, persyaratan-persyaratan kepada negara dalam karyanya, maka akan segera nampak bahwa tugas dan fungsi pemerintah dan negara yang dibebankan di atas pundak kepala negara adalah untuk mensejahterakan (al-falah) rakyatnya, baik secara spiritual (ibadah), ekonomi, politik dan hak-hak individual (privat: hak Adami) secara berimbang dengan hak Allah atau publik. Tentu saja termasuk di dalamnya adalah pengelolaan harta, lalu lintas hak 
dan kepemilikan atas harta perniagaan, produksi barang dan jasa, distribusi serta konsumsi-nya yang kesemuanya adalah obyek kajian utama ilmu ekonomi.

” Dalam Encyclokipaedia Britania, Jerome Ravetz menulis Eropa masih berada dalam kegelapan, sehingga tahun 1000 Masehi di mana ia dapat dikatakan kosong dari segala ilmu dan pemikiran, kemudian pada abad ke 12 Masehi, Eropa mulai bangkit. Kebangkitan ini disebabkan oleh adanya persinggungan Eropa dengan dunia Islam yang sangat tinggi di Spanyol dan Palestina, serta juga disebabkan oleh perkembangan kota-kota tempat berkumpul orang-orang kaya yang terpelajar”.

Dalam konteks inilah perkembangan ilmu ekonomi tidak sepenuhnya milik barat. Dengan demikian keberadaan Filsafat Islam, bagaimanapun, harus diakui sebagai jembatan emas bagi perkembangan pengkajian filsafat di Eropa. Kontribusi pemikiran Islam selalu dianggap tidak ada, sumber pemikiran modern selalu dirujukkan pada pemikiran Yunan (dan Bible). Samuelson, misalnya, dalam buku teks Economics edisi 7, menyebutkan bahwa asal muasal Ilmu ekonomi adalah Bible (Injil) dan filsafat Yunani -tanpa menyebut kontribusi Filsuf Muslim terhadap perkembangan kajian ekonomi. Demikian juga dengan A History of Economic Thought yang ditulis John Fred Bell (1967). Bagi Samuelson St Thomas Aquinaslah sumber inspirasi utama dari pemikiran Quesney dan Merkantilis, lalu dari kedua pemikir ini menjadi basis bagi pemikiran yang digagas oleh Adam Smith. Kita tahu, Adam Smith adalah tokoh utama dari pemikiran ekonomi konvensional. Bermula dari Adam Smith inilah kita mengenali teoti motif ekonomi, invisible hand, pasar bebas, dan sejenisnya.

Abdul Azis Islahi pada tulisan The Myth of Bryson and Economic Thought in Islam mengemukakan bahwa Filsuf Muslim tidak menerjemahkan The Greek oikonomia dengan bahasa Arab ,ilm tadbir al-manzil (the science of household management) namun juga menambahkan ruang lingkup bahasan ekonomi. Jika ekonomi Yunani 
terbatas pada pembahasan gagasan, wants and their satisfactions, economy of self sufficient households, division of labour, barter, and money. Filsuf Muslim memperluasnya ke wilayah market function and pricing mechanism, production and distribution problems, government economic role and public finance, poverty eradications, and economic development, etc. Kesimpulan Islahi ini diperkuat dengan tulisan Spengler (1964, p. 304) yang menegaskan bahwa "Muslim scholars extended this branch of knowledge „far beyond the household, embracing market, price, monetary, supply, demand phenomena, and hinting at some of the macro-economic relations stressed by Lord Keynes ${ }^{e e}$.

Dalam jurnal Abdul Aziz Islahi dikatakan Unsur-unsur yang ditekankan oleh para penulis Muslim adalah: kesetaraan dan keadilan sosial, amanah (kepercayaan), ithar (pengorbanan), tazkiyah (pemurnian diri), etika dan spiritualitas, penyediaan institusi sadaqah (amal), hibah (hadiah), wakaf (wakaf), wasiyyah (wasiat), 'ariyah (pinjaman tanpa biaya apapun), pelarangan bunga, pencegahan pemborosan.

Hal inilah yang akan dilihat dalam penelitian ini tentang bagaimana unsurunsur yang ditekankan dalam syariah islam akan berdampak terhadap pertumbuhan ekonomi pada negara-negara yang menerapkan prinsip ekonomi syariah. Berikut beberapa pendapat pro dan kontra terhadap berbagai jurnal penelitian mengenai prinsip ekonomi dan pertumbuhan ekonomi.

Baik Plato dan al-Ghazali mendiskusikan 'pembagian kerja'. Tetapi Plato pandangan adalah 'kasta'. Dia tidak menekankan pada 'peningkatan efisiensi yang dihasilkan dari pembagian kerja '(Schumpeter, 1997, hal. 56), sementara al- 
Ghazali (n.d. Vol.4, pp: 91- 92), seperti Adam Smith, menyoroti efisiensi ekonominya.

Al-Ghazali, Ibnu Khaldun dan banyak ulama Muslim lainnya memegang prinsip bahwa logam mulia diciptakan untuk berfungsi sebagai uang, ide asal Yunani (Schumpeter, 1997, hal. 62), tetapi Ibnu Taimiyah (1963, Vol. 19, pp.250, 251, 248-249) menganggapnya sebagai masalah konvensi. Dia mengatakan: 'Koin emas dan perak tidak memiliki spesifikasi alami atau Syariah. Mereka bergantung pada orang-orang, kebiasaan dan konsensus sosial mereka, sehingga setiap komoditas dapat berfungsi sebagai uang. 'Bahkan koin (uang token) yang beredar akan memerintah sebagai logam mulia dalam mengukur nilai barang' (ibid., Vol. 29, hal. 4) Kontroversi tentang dampak nyata dari perkembangan keuangan pada pertumbuhan ekonomi juga tampak dalam penelitian empiris. Beberapa penelitian menunjukkan efek menguntungkan dari pengembangan perbankan terhadap pertumbuhan ekonomi (Ratsimalahelo dan Barry, 2010; Abu-Bader dan Abu Qarn, 2008; Galindo et al., 2007; Shan dan Jianhong, 2006; Cull dan Xu, 2005; Guiso et al. , 2002; Raja dan Levine,1993). Sebaliknya, penelitian lain telah menunjukkan efek buruk dari pembangunan perbankan pada pertumbuhan ekonomi atau campuran antara efek positif dan negatif (Guillaumont-Jeanneney dan Kpodar, 2006; Rancière et al., 2006; Eggoh, 2010). Karena itu kita harus bertanya pada diri kita sendiri: Mengapa kita begitu tertarik pada subjek yang telah banyak dibahas dalam literatur sebelumnya? Nah, sebagian besar riset itu mengeksplorasi hubungan antara pembangunan perbankan dan pertumbuhan ekonomi didasarkan pada sampel dari negara-negara maju dengan sistem perbankan dan pasar keuangan yang ditandai dengan kurangnya informasi asimetri, biaya transaksi 
yang lebih rendah, dan regulasi perbankan yang lebih efektif bila dibandingkan dengan negara-negara berkembang. Juga tidak pasti apakah kesimpulan penelitian tentang pengaruh pengembangan keuangan pada pertumbuhan juga berlaku untuk sistem di mana bank-bank Islam memainkan peran penting.

Majid dan Kassim (2010) secara empiris memeriksa hubungan antara keuangan Islam dan pertumbuhan ekonomi dan menunjukkan, dengan mengacu pada studi Patrick (1966), pendekatan suplai terkemuka, di mana arah kausalitas berjalan dari pengembangan keuangan Islam ke pertumbuhan ekonomi Abduh dan Omar (2012), sementara itu, mengembangkan analisis kointegrasi data triwulanan untuk periode 2003-2010 untuk mempelajari hubungan antara pengembangan perbankan Islam dan pertumbuhan ekonomi di Indonesia. Mereka menunjukkan bahwa kausalitas antara pengembangan perbankan Islam dan pertumbuhan ekonomi dua arah, yang berarti bahwa pertumbuhan ekonomi mendorong bankbank Islam untuk berkembang lebih lanjut, yang pada gilirannya merangsang pertumbuhan ekonomi di Indonesia.

Menggunakan teknik deret waktu, Abduh et al. (2012) mempelajari hubungan antara perkembangan perbankan Islam dan konvensional dengan pertumbuhan ekonomi di Bahrain. Hasilnya menunjukkan hubungan dua arah positif dan signifikan antara keuangan Islam dan pertumbuhan ekonomi jangka panjang. Namun, hubungan ini tidak terbukti dalam jangka pendek. Sebaliknya, perkembangan perbankan konvensional secara signifikan terkait dengan pertumbuhan ekonomi baik dalam jangka panjang dan pendek. Mosab dan Tabash (2014), sementara itu, mengevaluasi hubungan antara perkembangan keuangan Islam dan pertumbuhan ekonomi di Qatar untuk periode 1990-2008. Hasilnya 
menunjukkan bahwa perkembangan jangka panjang pembiayaan Islam secara positif terkait dengan pertumbuhan ekonomi, tetapi dalam jangka pendek, tes kausalitas Granger menunjukkan adanya hubungan dua arah antara perkembangan keuangan Islam dan pertumbuhan ekonomi. Untuk bagian mereka, Farahani dan Dastan (2013) mempelajari hubungan antara keuangan Islam pembangunan dan pertumbuhan ekonomi dalam sampel delapan negara (Bahrain, UAE, Arab Saudi, Kuwait, Qatar, Yaman, Malaysia, Indonesia, dan Mesir) untuk periode 2000-2010. Hasilnya menunjukkan bagaimana perkembangan keuangan Islam secara positif mempengaruhi pertumbuhan ekonomi jangka panjang. Selain itu, Abedifar et al. (2016) membahas pentingnya bank-bank Islam dan rekanrekan konvensional mereka, serta hubungan antara perkembangan keuangan danpertumbuhan ekonomi. Studi mereka didasarkan pada sampel 22 negara Muslim dengan sistem perbankan ganda untuk periode 1999-2011. Hasilnya menunjukkan hubungan yang positif dan signifikan antara pangsa pasar bank syariah dan perkembangan keuangan intermediasi, pendalaman keuangan, dan pertumbuhan ekonomi, terutama di negara-negara berpenghasilan rendah dan negara-negara mayoritas Muslim. Selain itu, hasilnya juga menunjukkan pasar yang lebih besar saham untuk bank syariah dikaitkan dengan efisiensi yang lebih besar untuk bank konvensional. Berbeda dengan di atas, beberapa penelitian telah menyimpulkan bahwa perkembangan bank syariah memiliki tidak berdampak pada pertumbuhan ekonomi. Sebagai contoh, Goaied dan Sassi (2010) meneliti hubungan antara perkembangan keuangan dan pertumbuhan untuk 16 negara MENA. Mereka mencoba memverifikasi pengaruh spesifik dari kredit yang dikeluarkan untuk sektor swasta oleh bank syariah pada pertumbuhan ekonomi 
menggunakan penduga sistem GMM. Hasil penelitian menunjukkan tidak ada hubungan yang signifikan antara pengembangan perbankan dan pertumbuhan ekonomi, sehingga memperkuat gagasan bahwa bank tidak merangsang pertumbuhan ekonomi. Selain itu, mereka menemukan bahwa untuk spesifikasi tertentu, perbankan indikator berhubungan negatif dan signifikan dengan pertumbuhan. Pengamatan lebih lanjut mengungkapkan bahwa bank syariah tidak terkecuali di pasar keuangan dan hanya menunjukkan yang lemah hubungan dengan pertumbuhan. Selain itu, hubungan antara keuangan dan pertumbuhan ekonomi bervariasi antar wilayah dan pendapatan tingkat dan berbeda di antara negara-negara pengekspor minyak (Barajas et al., 2013). Berdasarkan sampel dari 150 negara untuk periode 1975-2005, Barajas et al. (2013) menunjukkan hubungan pertumbuhan ekonomi-keuangan menjadi lebih lemah di negara-negara pengekspor minyak di kawasan MENA dan di negara-negara berpenghasilan rendah. Analisis lebih lanjut menunjukkan bahwa perbedaan ini dapat didorong oleh karakteristik dan pemantauan peraturan, serta terkait dengan variasi dalam akses yang luas ke layanan keuangan.

\section{Kesimpulan}

Filsafat ekonomi merupakan dasar dari sebuah system ekonomi yang dibangun. Berdasarkan filsafat ekonomi yang ada dapat diturunkan tujuan-tujuan yang hendak dicapai, misalnya tujuan kegiatan ekonomi konsumsi, produksi, distribusi, pembangunan ekonomi, kebijakan moneter, kebijakan fiskal, dsb.

Filsafat ekonomi Islam didasarkan pada konsep triangle: yakni filsafat Tuhan, manusia dan alam. Kunci filsafat ekonomi Islam terletak pada manusia 
dengan Tuhan, alam dan manusia lainnya. Dimensi filsafat ekonomi Islam inilah yang membedakan ekonomi Islam dengan system ekonomi lainnya kapitalisme dan sosialisme. Filsafat ekonomi yang Islami, memiliki paradigma yang relevan dengan nilai-nilailogis, etisdanestetis yang Islami yang kemudian difungsionalkan ketengah tingkahlaku ekonomi manusia. Dari filsafat ekonomi ini diturunkan juga nilai-nilai instrumental sebagai perangkat peraturan permainan (rule of game) suatu kegiatan.

Islam bukan sekedar menawarkan pedoman-pedoman moral teoritis guna membangun sistem ekonomi, tapi juga mengemukakan suatu metodologi yang layak untuk menerapkan pedoman-pedoman dengan keabsahan cara dan juga legitimasi tujuan dengan landasan atas pertimbangan etika yang jelas dan dapat bemakna di dalam keseluruan kerangka tata sosial, dengan pendekatan terhadap sistem ekonomi ini sangat relevan dan amat mendesak untuk di alamatkan pada syari'ah dengan filsafat ekonomi Islam.

Pada masa dahulu aplikasinya sangat sederhana dan berlangsung antara dua pihak. Pada masa sekarang ketika mudharabah masuk dalam dunia perbankan aplikasinya mengalami pengembangan. Demikian pula penerapan bai' istishna' dalam pembangunan suatu proyek. Ini adalah pengembangan dari konsep jual beli yang diajarkan Al-quran dan Sunnah. Tugas cendikiawan muslim sepanjang sejarah adalah mengembangkan teknik penerapan prinsip-prinsip tersebut sesuai dengan situasi, kondisi dan perkembangan zaman. Dengan demikian ciri khas aspek muamalat (ekonomi) adalah cakupannya yang luas dan bersifat elastis, dapat berkembang sesuai dengan perkembangan zaman dan perubahan tempat. 
Ajaran muamalat khususnya dalam ekonomi lebih tampak sifat universalnya. Hal ini karena dalam bermuamalat di bidang ekonomi tidak membeda-bedakan muslim dan non-muslim. Kenyataan ini tersirat dalam suatu ungkapan yang diucapkan oleh Khalifah Ali bahwa dalam bidang muamalat kewajiban mereka adalah kewajiban kita dan hak mereka adalah hak kita. Filsafat ekonomi islam, merupakan dasar dari sebuah sistem ekonomi yang dibangun berdasarkan falsafah ekonomi yang ada, sehingga dapat diturunkan tujuan-tujuan yang hendak dicapai, misalnya tujuan kegiatan ekonomi konsumsi, produksi, distribusi, pembangunan ekonomi, kebijakan moneter, kebijakan fiskal, dan sebagainya. 